\title{
The management of culture and environment of madrasah: Its implementation and challenges in industrial revolution era 4.0
}

\author{
Herson Anwar *, Lukman Arsyad, Arten H. Mobonggi \\ IAIN Sultan Amai Gorontalo. Jalan Gelatik No.1 Kota Gorontalo, Gorontalo 96114, Indonesia. \\ * Corresponding Author. Email: herson.anwar@iaingorontalo.ac.id
}

Received: 24 July 2020; Revised: 2 August 2020; Accepted: 30 August 2020

\begin{abstract}
This study aims to review the implementation of the management of culture and environment of madrasah and the challenges faced, especially the private Madrasah at Gorontalo. The method used in this study is a naturalistic-qualitative study. The data were collected through observation, interview, and documentation. The findings obtained showed that the culture and environment at the private Madrasah Ibtidaiyah at Gorontalo were various in physical culture and behavioural culture. The physical culture can be seen from physical appearance of madrasah which has different characteristics. The form of physical culture involved can be seen from the facilities, school building with fence, motto, and writing in the wall which support the development of expected culture. The behavioral culture can be seen from religious culture, discipline culture, and the implementation of the rules, achievement and competition culture, reading and clean culture. The implementation of the management of culture and environment of madrasah is in line with the vision, mission, and the goals of the school realized in the form of programs regarding the creation of culture and environment of madrasah by improving the participation of all people in madrasah in order to optimize the facilities which support cultural values that become the priority of each private Madrasah Ibtidaiyah in Gorontalo. In order to solve the problems, the awareness and commitment of people in madrasah are totally required especially in the fixing of learning system and the enforcement of disciplines, which cultural values are important and unimportant. Besides that, the harmonious cooperation among all people in madrasah is essentially needed in managing the culture and environment of madrasah to elevate the competitiveness..
\end{abstract}

Keywords: management, culture, environment, Private Madrasah Ibtidaiyah.

How to Cite: Anwar, H., Arsyad, L., \& Mobonggi, A. (2020). The management of culture and environment of madrasah: Its implementation and challenges in industrial revolution era 4.0. Jurnal Prima Edukasia, 8(2), 188-198. doi:https://doi.org/10.21831/jpe.v8i2.33488

\section{Introduction}

Every madrasah (Islamic school) is a unique system that has personality and identity, therefore it also has a unique culture. Madrasah has the uniqueness which is appropriate with the core of business in running the organization which has its own culture and influenced by the values, perceptions, habits, educational policies, and the behaviors of people within it, so madrasah should show its capability which is suitable with the learning demands, namely to teach students as the principles of humanity and Islam (Mutohar, 2016). It is a strategic chance to make madrasah as a better school than public school in industrial revolution era 4.0. It is tempting to assume that all madrasah are broadly similar: religious schools that prioritize a range of Islamic subjects while failing to offer broad-based curricula that include modern subjects, whether science, the social sciences, or contemporary languages (Evans, 2008).

The industrial revolution era 4.0 brings significant effects to all aspects of life including the management of education in madrasah. For instance, the madrasah education systems in Indonesia, Nigeria, and Bangladesh served as low-cost platforms to achieve universal education and the target of gender equiti in schooling (Asadullah, Amin, \& Chaudhury, 2019). According to Priatmoko (2018) the education in 4.0 era is a phenomenon which responses the needs of the fourth industrial revolution where human and machine are synchronized to obtain solution and new innovation. In the other side, the reality of human's living has entered the technological revolution era which fundamentally change the way of living, working, and communicating to each other (Ghazali, 2018). The education in this era has big responsibilities, according to Nugraha, Maskar \& Rohyani (2016) that the education should prepare 
students in facing three things, they are: (1) preparing the students to work in the future; (2) preparing the students to solve their problem in the future, and (3) preparing students to use, utilize, and manage the technology in the future. Therefore, this era is indicated to create a disruption phenomenon which is faced to the challenges, demands, and the new needs. It also demands educational stakeholders to adapt with the renewal and innovation of system in this era.

Madrasah as the part of Islamic education institution has big responsibilities in anticipating negative effect of global culture in the industrial revolution era 4.0. It develoved into madrasah, a school managed by the community where teaching is based on Qur'an, Islam, and moral education (Sali \& Marasigan, 2020). In general, the community does not know and understand clearly what is a madrasah and what is a school. In general, the community does not know and understand clearly what is a madrasah and what is a school. Madrasahs are often understood as non-formal education for madrasah diniyah which implements learning every evening (Abrori \& Hadi, 2020). A search for scholarly writings, on the history of madrasah eucation and its developments in the modern period, reveals a preponderance of literature that for the most part documents men's establishment of, and leadership and participation in madrasahs (Hoel, 2016). Chaer (2016) states that madrasah has ideal roles in anticipating negative effects of global culture which contains western cultures with negative access such as materialistic, secular, and consumptive life styles which are contrast to Islamic values. Whereas, that ideal role will optimally create good muslim generations which are able to compete globally. Yet, the reality shows that madrasah is left behind from public school, especially private madrasah. According to Anwar $(2017$, p. 4), the inferiority of private madrasah is caused by the limited funds, the lack of supporting facilities, and the weak pattern of management system. Besides that, the service provided is also unconducive, where the management is not transparent and not accountable, including the cooperation intensity among related components such as between the member of foundation boards and madrasah, students' parents, which are considered to give lack contribution for the development of private madrasah, including the private madrasah ibtidaiyah in Gorontalo.

The private Madrasah Ibtidaiyah (Islamic elementary school) in Gorontalo have various performances; from high quality to poor quality. That kind of variation is actually not a pride, otherwise, because the people only see the negatives. If it is compared to favourite elementary schools in Gorontalo, then the private madrasah is inferior because public school is still the favourite. Many private Madrasah Ibtidaiyah in Gorontalo are difficult to maintain their existence to compete with the other schools. Generally, private Madrasah Ibtidaiyah in Gorontalo still face some problems which affect the quality of the process and the result, which is related to students' background and their family, the support from various education sources, the qualification and the low participation of people.

Based on the survey regarding the private Madrasah Ibtidaiyah in Gorontalo, it indicates some influencing problems, whether in the management aspect or in the result. It can be seen from the academic potency of students in the private Madrasah Ibtidaiyah which is generally lower than the potency of students in the other schools. Obviously, it can be seen by seeing the achievements in the national examination where the numbers of students of the private Madrasah Ibtidaiyah is relatively lower than those in the other schools. The economy background of students who enter the private madrasah Ibtidaiyah in Gorontalo is from the low class, and the limited numbers of teachers with good qualification and the limited fund from the government and the society especially for improving the quality of the school. If the whole potency of the private Madrasah Ibtidaiyah in Gorontalo is well optimized, so the quality improvement from the aspect of process and achievement is obtained, although there are some problems faced.

As the effort to make the private Madrasah Ibtidaiyah in Gorontalo accepted broadly by people, the standardized educational management and the innovation are required in order to face the challenge in 4.0 era through the management of culture and environment in madrasah. The management in this sector is expected to realize the effective management of madrasah which has strong, creative profile and highly motivated. Improving the quality of the madrasah in the direction of improvement is a necessity amid tight competition among educational institutions in producing output quality (Kalebbi, 2014).

The form of the culture in madrasah as an organization appears as a unique and intersting phenomenon, because the perspective, attitude, and behaviour in the school reflect the deep and unique belief for all madrasah residents which function to build characters of students. It can be separated from various studies which interprete the culture itself. For example, a research conducted by Muhaimin, et 
al (2015: 48) which states that the madrasah culture is something established from the combination of values believed by all madrasah residents which appear in various symbols and behaviour which can be observed thoroughly in the daily life in madarasah. It is similar to Saminan (2015) who states that culture can be interpreted as the whole way of life, social heritage, way of thinking, belief, and the way the groups behave in the daily life which is reflected in the habit, custom, interaction pattern, belief, attitude, and special behaviour which is done repeatedly in certain society.

Related to the importance of the culture and environment of madrasah, they show the existence of the culture which has a very important role in improving the quality of madrasah. Zuhriy (2011) argues that each individual, community and society through their creations can create certain cultures, when the creations created are then repeated, and even then becomes a collective agreement then at that time the creations have been transformed into a culture. Anwar (2014) emphasized that culture is a very complex concept, which touches all aspects of life so that it may become life itself. According to Lathifah \& Rustono (2015) that in general, individuals are motivated by a culture that influences their behavior which requires them to give instructions about what must be followed and learned. This shows that each culture also seems to understand the meaning of culture with a perspective that is not always the same, highly dependent on the aspects of emphasis in that culture. The culture of a madrasah is closely related to the behavior and habits of the people in madrasah to make adjustments to the environment, as well as how to look at problems and solve them, so that it can provide a foundation and direction for an effective and efficient education process.

Madrasah culture is a set ofvalue systems believed to be formulated in a madrasah vision and mission as well as actualized in the lives of all citizens of the madrasah. If any madrasah hasl culture of each course will enrich and comparative advantage madrasas, however must be aligned with the value system of universal values that can be accepted by the whole society (Barnawi, 2013). Thus the substances of the culture in madrasah are the behaviors, values, attitudes and way of life of madrasah residents who are trying to dynamize the madrasah environment to achieve the goals. The positive madrasah culture will give its own color and in line with the implementation of madrasah-based management. These positive cultures include: a culture of honesty, a culture of mutual trust, a culture of cleanlinnes, a culture of discipline, a culture of reading, a culture of cooperation, a culture of giving a rebuke and appreciation.

For this reason, the culture and environment of a madrasah need to be managed with good management. The management of madrasah culture and environment has a great opportunity in producing graduates with good character values so that education can take place as a real effort to create a conducive learning atmosphere and learning process so as to produce students who are not only cognitively intelligent but also students with positive character. The culture found in madrasah is the dominant values supported by madrasah that guide madrasah policies towards all elements and components of schools including education stakeholders, such as how to carry out work in madrasah and basic assumptions or beliefs held by madrasah residents.

The development of madrasah culture should always refer to the ability of madrasah principals in developing the culture of execuence in madrasah. Meanwhile, the madrasah environment is an educational institution which has an unwritten culture that defines standards of behavior that are well accepted, implicit in the dominant culture of madrasah.Saparuddin (2014) suggests that a safe and orderly madrasah environment is shown by optimism and high expectations, from all madrasah residents, the formation of madrasah health, and student-centered activities are examples of madrasah culture that can foster enthusiasm for learning and improve teacher competency. This is also in line with the reality faced by madrasah now showing that madrasah in general experience a number of problems compared to the condition of public schools. According to Supriyanto (2015) the problems faced by madrasah include: the majority of madrasah at all levels are still private, people who tend to choose madrasah are influenced by practical-economic motives because the costs are cheap and are considered capable of meeting the basic needs of the community in the field of religious knowledge and practical skills. In addition, the low educational resources available in madrasah such as: the low quality of teachers, the low managerial ability of madrasah principals, even the bureaucracy that is considered to be able to determine policy, planning, management and evaluation is still very weak. The solution to this problem was emphasized by Muhaimin, et al $(2015$, p. 20) that the response to the anticipation of the problem of madrasah as an Islamic educational institution, seems to be very slow if managed improperly with its resources, without the efforts of togetherness, unity, and cooperation / partnerships which is mutually beneficial. 
Jurnal Prima Edukasia, 8 (2), 2020 - 191

Herson Anwar, Lukman Arsyad, Arten H. Mobonggi

These problems indicate that reviewing cultural and environmental management in Private Madrasah Ibtidaiyah in Gorontalo is an urgent matter to improve the management of madrasah culture and environment with various development programs that are able to overcome the various challenges faced by madrasah today. Madrasah culture and environment management is important, so that the madrasah environment can be a conducive place for developing an optimistic character, developing reasoning, enlightenment of the mind, equipping the skills and attitudes needed to make honest, polite, productive creative students, independent, and beneficial for others, because the madrasah environment is one of the places where students interact, in addition to the family and community environment to carry out the process of socialization, namely the socialization of values, knowledge, attitudes, and skills.

\section{Method}

This research is a qualitative research as an a priori approach based on philosophical assumptions (interpretive naturalistic approach) and multiple sources of information and narrative approaches available to researchers, because qualitative research techniques for collecting data are varied to obtain empirical data such as case studies, personal experience, self-evaluation, life stories, interviews, artifacts, cultural studies, observations, historical, and direct interactions \{Formatting Citation\}. Considering that, this study aims to describe the implementation of madrasah culture and environmental management in accordance with educational management standards and the challenges faced by Private Madrasah Ibtidaiyah, then this study was conducted in five Private Madrasah Ibtidaiyah (MI) in Gorontalo, namely Madrasah Ibtidaiyah Muhammadiyah, located in North City, Madrasah Ibtidaiyah Darul Mubin in the West City, in the East City there is Madrasah Ibtidaiyah Alwathaniyah and in the South City there is Madrasah Ibtidaiyah Al-Huda and in the Central City there is the Madrasah Ibtidaiyah Unggulan Muhammadiyah Gorontalo.

The data obtained were in the form of descriptive data results written or oral from the facts found in the field at the time of the study. Data obtained from observations, interviews and documentation. Data analysis in the study was carried out by several stages, namely: data collection, data reduction, data presentation, conclusion drawing and data verification. In addition, data editing, categorization / coding, and meaning making were codcted. In the process of editing data, the data was translated and converted. The data which was unable to be read then was translated into readability and comprehension. In the coding phase, data categorization was applied according to the focus of the research problems. To get the meaning, this research analyzed according to the focus of the problem must be given meaning. Conceptualization of scientific statements was also added as a conclusion of the study.

\section{Result and Discussion}

\section{The Implementation of the Management of Culture and Environment of Madrasah}

Madrasah culture and environment management in education management standards explained that schools/madrasah create the atmosphere, climate, and educational environment which are conducive to efficient learning in implementation procedures, establish guidelines for rules that contain the rules of educators, education personnel, and students, including in terms of using and maintaining educational facilities and infrastructure, instructions, warnings, and prohibitions in behavior, as well as sanctions for madrasah members who violate the rules and establish a code of ethics to uphold ethics in schools/ madrasah including in some Private Madrasah Ibtidaiyah in Gorontalo, namely Madrasah Ibtidaiyah Muhammadiyah Gorontalo, Madrasah Ibtidaiyah Darul Mubin, Madrasah Ibtidaiyah Alwathaniyah, Madrasah Ibtidaiyah Al-Huda and Madrasah Ibtidaiyah Muhammadiyah Gorontalo.

Related to the management of madrasah culture and environment in order to create a conducive atmosphere, climate and educational environment in Private Madrasah Ibtidaiyah in Gorontalo, it is obtained that the five madrasah have different programs in creating a conducive atmosphere, climate and educational environment such as joint healthy walk activities, there are study tours for students, study tours for teachers and staff, outbound, art and sport activities at Madrasah Ibtidaiyah Alwathaniyah, attend and return on time, flag ceremonies every Monday, make announcements that are important to be known by Madrasah residents in Madrasah Ibtidaiyah al- Huda, the implementation of $7 \mathrm{~K}$ in Madrasah Ibtidaiyah Muhammadiyah, student order operations and cleanliness movement through Friday and Saturday Clean, cleanliness contest at the end of each semester before receiving study report 
Jurnal Prima Edukasia, 8 (2), 2020 - 192

Herson Anwar, Lukman Arsyad, Arten H. Mobonggi

at Madrasah Ibtidaiyah Darul Mubin, structuring and maintaining a beautiful madrasah environment, integrated camp and tent camp i scout, meeting madrasah residents in the Madrasah Ibtidaiyah Muhammadiyah Unggulan Gorontalo.

Furthermore, in establishing guidelines for rules that contain the rules of teachers, education staffs, and students, it is obtained that every form of code of conduct made by private Madrasah Ibtidaiyah in Gorontalo has a direct influence on the lives and habits of madrasah residents both teachers, administrative staff, and students themselves. One of them is to arrive at the madrasah at exactly 6:45am. So that the teachers prepare themselves in the teaching process and by coming at $6: 45 \mathrm{am}$. The teachers will not be in a hurry so that they can prepare themselves properly. If the teachers arrive at the Madrasah for more than the stipulated hour, the teachers are not permitted to enter and will be given a sanction in the form of a reprimand. This applies to all teachers and employees in particular and students in general. This indicates that the code of conduct created aims to discipline teachers, employees and students. Discipline is an attitude that shows willingness to obey and obey a rule that is applied. The application of discipline aims to direct the behavior of teachers, employees and students to be in accordance with applicable rules or rules. Madrasah create rules to be obeyed and run by teachers which are the consequences of being madrasah citizens.

The form of public order that is applied to teachers, administrative staff, and students shows that the rules of discipline made in the Private Madrasah Ibtidaiyah in Gorontalo are related to disciplinary rules including arriving on time, always following madrasah activities, both internal and external. The code regulates the things that must be done by teachers, employees and students relating to teaching and learning activities, the implementation of madrasah programs and maintaining the good name of madrasah. Coming to the madrasah on time is a must for teachers and staffs, because it shows that they have implemented one of the other disciplines that must be met. Madrasah always emphasizes teachers to arrive on time and if they are late, they will get sanctions. With the habit of coming on time train teachers and employees to discipline themselves before disciplining others in the sense of students. In addition to the rules, the efforts undertaken by madrasah were to instill three disciplines, namely time discipline, worship discipline and teaching discipline. In this time discipline is related to discipline when it comes to madrasah, discipline when leaving madrasah and discipline to rules and regulations of madrasah. In terms of religious discipline, teachers and employees are expected to give examples to students. For example, the discipline of prayer that is carried out in congregation is accompanied by prayers. The teacher must set an example for students by disciplining in teaching, that is, entering according to the adjusted hours, the tasks given are always corrected, there is assertiveness in assigning grades and assigning tasks and leaving the class in accordance with the time provided.

Meanwhile, in establishing disciplines and ethics code to uphold ethics in madrasah, it is obtained that the ethics code is installed in strategic places, teacher rooms, staff rooms, and others. For the rules also always echoed in every activity in the madrasah. Ethical awareness program by disseminating $7 \mathrm{~K}$ programs (devotion, safety, cleanliness, orderliness, cleanliness, family, shade) and Senyum (smile), Sapa (greeting), Salam (greeting) or abbreviated as 3S. While the madrasah's code of ethics covers teachers and education personnel, while the one who determines is the madrasah principal by considering input from madrasah residents, namely teachers, employees, madrasah committees and students.

Ethical awareness programs are manifested in the form of appeals to students, including using slogans and motivational phrases such as the slogan "LISA" (Lihat Sampah Angkat which means see rubbish, take to rubbish can!), "Jagalah Kebersihan" which means keep the cleanliness, "Keberhasihan Bagian dari Iman" which means Cleanliness is the part of faith, "Bersih itu Indah" which means clean is healthy, and "Bersih Pangkal sehat" which means clean is the health base". There are also rules that are made about the provision of fines to students in the amount of Rp. 2000.- every violated the rules of madrasah. Based on the results of observing documents, the madrasah rules govern the activities of educators, education staff, and students. The rules for teachers and administrative staff include time to attend and go home, information about not entering school, protecting the environment, about official uniforms, and the types of prohibitions that teachers and employees must avoid. The rules for students include school clothes, hair, tattoos, nails, and make-up, school entry and return, cleanliness, discipline, and order, social courtesy, flag ceremonies and holidays, religious activities, restrictions, and violations and sanctions. As stated by Yulianto (2020) values and beliefs will not be present in a short time, it needs a long and continous process. 
Thus related to the findings of the management of madrasah culture and environment in the Pivate Madrasah Ibtidaiyah in Gorontalo obtained an illustration that in the aspects of madrasah discipline arrangement, code of ethics, and ethical awareness programs, realized through a variety of activities together with stakeholders with students, such as joint healthy walk activities, there are study tours for students, study tours for teachers and staffs, outbound, sport and art activities at Madrasah Ibtidaiyah Alwathaniyah, attend and return on time, flag ceremonies every Monday, make announcements that are important to be known by Madrasah residents in Madrasah Ibtidaiyah al- Huda, the implementation of $7 \mathrm{~K}$ in Madrasah Ibtidaiyah Muhammadiyah, order operation of students and cleanliness through Friday and Saturday Clean, cleanliness contest at the end of each semester before receiving academic report at Madrasah Ibtidaiyah Darul Mubin, structuring and maintaining the madrasah environment which is beautiful, integrated camp and clean camp at the end of the semester before receiving academic report at Madrasah Ibtidaiyah Darul Mubin, structuring and maintaining the madrasah environment which is beautiful, scout integrated camp and tent camps, the meeting of the Madrasah community in Madrasah Ibtidaiyah Muhammadiyah, Gorontalo. A conducive atmosphere is carried out by making rules in the form of madrasah regulations and through appeals to protect the environment. Based on the results of these studies, the implementation of aspects of the business creates a conducive atmosphere, climate and educational environment in accordance with the specified indicators.

Compilation of rules in Private Madrasah Ibtidaiyah in Gorontalo is used to regulate the activities of students, madrasah code of ethics to regulate the activities of educators and education personnel, ethical awareness programs are carried out to conduct program socialization to each madrasah. Madrasah code of conduct is socialized to each student through the explanation of the beginning of the new school year by giving Madrasah code of conduct. The code of ethics is placed in every madrasah room, so it becomes a reminder for educators and education staff. The ethical awareness program is implemented through making appeals to all madrasah residents in the form of catchy slogans. Based on the results of the study, the implementation of the aspects of the preparation of madrasah rules, code of ethics, and ethical awareness programs are in accordance with the established indicators.

Based on the results of observing documents, the madrasah rules govern the activities of teachers, education staff, and students. The rules for teachers and administrative staff include time to attend and return, information about not entering school, protecting the environment, about official uniforms, and the types of prohibitions that teachers and employees must avoid. The rules for students include school clothes, hair, tattoos, nails, and make-up, school entry and return, cleanliness, discipline, and order, social courtesy, flag ceremonies and holidays, religious activities, restrictions, and violations and sanctions. From the findings of the interviews and observations related to the management of the field of culture and environment in Private Madrasah Ibtidaiyah in Gorontalo obtained the following picture.

First, in the aspect of compiling the madrasah code of conduct, code of ethics, and ethical awareness program, it is realized through various activities with stakeholders and students, such as healthy walking activities, there are study tours for students, study tours for teachers and employees, outbound, traditional activities at Madrasah Ibtidaiyah Alwathaniyah, present and returning on time, the flag ceremony every Monday, making important announcements to be known by madrasah residents at Madrasah Ibtidaiyah al-Huda, 7K implementation in the Ibtidaiyah Muhammadiyah Madrasah, the operation of order of students and the cleanliness movement through Clean Friday and Saturday, cleanup competition at the end of each semester before the reception of academic report at the Ibtidaiyah Darul Mubin Madrasah, the arrangement and maintenance of a beautiful madrasah environment, integrated camp and scout camp, the gathering of madrasah residents in Madrasah Ibtidaiyah Muhammadiyah, Gorontalo Superior. A conducive atmosphere is carried out by making rules in the form of madrasah regulations and through appeals to protect the environment. Based on the results of these studies, the implementation of aspects of the business creates a conducive atmosphere, climate and educational environment in accordance with the specified indicators. Second, the Compilation of the order in Private Madrasah Ibtidaiyah in Gorontalo is used to regulate the activities of students, the code of ethics of the madrasah to regulate the activities of educators and educational staff, ethical awareness programs carried out to carry out program socialization to each madrasah. Madrasah code of conduct is socialized to each student through the explanation of the beginning of the new school year by giving Madrasah code of conduct. The code of ethics is placed in every madrasah room, so it becomes a reminder for educators and education staff. The ethical awareness program is implemented through making appeals to all madrasah residents in the form of catchy slogans. 
Based on these findings, the management of madrasah culture and environment in the five private Madrasah Ibtidaiyah in Gorontalo is implemented in the form of diverse cultural values supported by the madrasah environment, each of which has different characteristics. In theory this is in line with Muhaimin, Sutiah \& Prabowo (2015, p. 55) which states that the values which are pillars of school/ madrasah culture can be prioritized on certain values and can be changed with other values that are in accordance with the focus of adaptation and madrasah environment. Madrasah that are focusing on external factors with unstable environmental conditions, will be very suitable if the cultural values that become priorities have a culture that is responsive to environmental changes such as: innovative, adaptive, hard working, and care for others. This condition might be very different from madrasas that focus on external factors but with a stable environment, it would be appropriate to have a visionary culture and people understand their role in carrying out work with values that can be prioritized are: initiative, togetherness, responsibility, ownership, and commitment to the madrasah. Whereas the madrasah that focuses on internal factors with a stable environment can develop a culture that supports cooperation and achievement of effective and efficient goals with prioritized values such as: cooperation, mutual understanding, the spirit of unity, obeying the principle, motivating, and guiding. If described in the quadrant form the relationship between external conditions, environmental conditions, culture of schools/madrasah, and values that can be a priority. The quadrant above shows that the values developed by madrasah can differ from one quadrant to another quadrant. This difference according to Muhaimin, Sutiah \& Prabowo (2015, p. 55) is influenced by the focus of the madrasah and its environmental conditions, although the overall values held in all quadrants are very good values and are important for madrasah to have, sometimes these values be something that is very priority to be implemented in accordance with the conditions owned by the madrasah. Newly established madrasah will certainly focus more on internal conditions with an unstable environment, so it will be very good and will certainly be very easy to develop if all madrasah components have high initiative in working, have togetherness in carrying out every madrasah activities, everyone in madarasah is people who are responsible for the various tasks they carry, a sense of belonging to a high madrasah, and have a commitment to the madarasah. Furthermore, the madrasah that has been in a stable condition and focusing on external factors will require the values of discipline, honesty, simple relationships between people or sections, and broad-minded. The values of discipline are needed to always be a trend setter to work on priorities and finish them thoroughly. While madrasah are already superior, of course they already have very large capital, so that sometimes the madrasah becomes reckless towards priorities and doing something that is not important takes precedence over something that is not important. It is here that it is important to manage cultural values and keep all people in the madrasah environment aware of what is important and priority, and which are not important and should be abandoned. It illustrates, once again, the ability of a successfully developmentalist state to optimise its human capital by making tactical changes through reforming madrasah education in age of globalisation (Tan, 2009, 2010). There are only a few madrasah in West Africa where students obtain a broad based Islamic education. In contrast the Arab countries mainly have governments who manage the curriculum and ensure that some secular subjects are taught in these institutions. In South East Asia, such as Indonesia and Malaysia, they have a similar approach to the Arab countries (Sabki \& Hardaker, 2013).

The Challenges of the Management of Culture and Environment of Madrasah

Culture refers to a system of values, beliefs and norms that are mutually accepted, and implemented with full awareness as a natural behavior, formed by the environment that creates a common understanding among all elements and personnel of the madrasah whether the headmaster, teachers, staff, and students. But in its implementation there are still various challenges faced, including in five private Madrasah Ibtidaiyah in Gorontalo, by examining various factors that become obstacles, as follows.

The inhibiting factor in the management of Madrasah culture and environment in the Madrasah Ibtidaiyah Alwathaniyah, according to the madrasah principal, is that there is still low awareness and habits to take care of all the existing infrastructure facilities and protect them, which still must continue to be cultivated because they will be very consuming school budgets if all funding allocations are only for the procurement of infrastructure. Efforts are made by continuing to urge and invite every school citizen to always maintain school facilities and infrastructure, especially teachers who teach last hours, monitor the cleanliness of each class, to run class picket every day and also continue to monitor the 
cleanliness of the madrasah environment to reduce the budget for cleaning facilities that evey month shuld be expensed.

Likewise in Madrasah Ibtidaiyah al-Huda, which becomes obstacle to the management of the cultural and environmental fields of madrasah in this Madrasah Ibtidaiyah is the lack of awareness of madrasah civilians cultivating cleanliness and maintaining existing facilities and infrastructure. According to the headmaster of madrasah that the inhibiting factor is the habit of always caring for possessed goods also must still be considered given the facilities, facilities and infrastructure of madrasah that are quite complete and adequate if not regulated in maintenance management this will certainly spend budget for re-procurement of goods. In this connection, the madrasah must make changes by familiarizing the culture of reading and management of care for the continuity of all activities in the madrasah.

Another case is an inhibiting factor in the management of madrasah culture and environment in Madrasah Ibtidaiyah Muhammadiyah, according to the madrasah principal, namely the low development of disciplinary culture and enforcement of madrasah disciplines such as the presence of some teachers who still use their feelings in upholding discipline, so that many students violate rules when dealing with certain teachers who often ignore the violations they have committed. Other inhibiting factors are from students. The attitude of students who are still unstable, so they consider committing an offense is something to be proud of if not caught.

Inhibiting factors in the management of madrasah culture and environment in the Madrasah Ibtidaiyah Darul Mubin, according to the madrasah head teacher, is that there are still some students who do not understand the meaning of the madrasah code of conduct, the demographic location of this madrasah which is in the middle of the city so that it greatly affects the character of the students. students who are on average are children with moderate intelligence and even have low, family backgrounds of students who are less directing their children to always be orderly in life. While the inhibiting factors in the management of madrasah culture and environment in the Madrasah Ibtidaiyah Muhammadiyah unggulan Gorontalo, according to the madrasah head teacher is that order and discipline are not optimal, because there are sometimes the presence of a number of picket teachers who are sometimes present between 07.15 to 07.30 , when in fact teachers should be picket should not be optimal present at 07.00 according to the commitments agreed upon by the madrasah so that its contribution to order and discipline as well as service to madrasah in the initial activities before learning in the first hour becomes less optimal. Another obstacle is that almost every day there are still some students who are late due to quite diverse reasons, for example, because they wake up late, the distance of the house is too far from the school and so forth which realistically the reasons submitted are still acceptable.

Looking at various factors that hinder the management of cultural and environmental communities in the five private Madrasah Ibtidaiyah in Gorontalo, various challenges faced in the management of the culture and environment of the madrasah, such as: challenges in Madrasah Ibtidaiyah Alwathaniyah are still low awareness and habits to treat all the infrastructure that already exists and safeguards it must still continue to be cultivated because it would be very costly for the school budget if all the funds were allocated only for the procurement of infrastructure. The madrasah head continues to appeal and invite every school citizen to always maintain school facilities and infrastructure, especially the teacher who teaches the last hour, the madrasah principal urges to monitor the cleanliness of each class, to run class picket every day and also to continue to monitor the state of the facility cleanliness to reduce the budget for cleaning facilities that have a monthly expenditure.

Likewise in Madrasah Ibtidaiyah al-Huda, which is a challenge in the management of the cultural and environmental fields of madrasah in this Madrasah Ibtidaiyah is the lack of awareness of madrasah civilians cultivating cleanliness and maintaining existing facilities and infrastructure. The habit of always taking care of the goods owned also still needs to be considered given the facilities, facilities and infrastructure of madrasah that are quite complete and adequate if not regulated in maintenance management, this will certainly suck up the madrasah budget for re-procurement of goods. In this connection, the madrasah must make changes by familiarizing the culture of reading and management of care for the continuity of all activities in the madrasah.

Another challenge faced in the management of the culture and environment of the madrasah in the Madrasah Ibtidaiyah Muhammadiyah, namely the low development of a culture of discipline and the enforcement of the madrasah discipline as there are some teachers who still use their feelings in upholding discipline, so that many students violate the rules when dealing with madrasah. certain teachers who often ignore the violations they have committed. Other challenges faced are from students. 
The attitude of students who are still unstable, so they consider committing an offense is something to boast of if not knowledgeable.

The challenges faced in managing the madrasah culture and environment in Madrasah Ibtidaiyah Darul Mubin, is that there are some students who do not understand the meaning of the rules in madrasah, the demographic location of this madrasah which is in the middle of the city so that it greatly influences the character of the students, the average student input -a average is a child with moderate intelligence and even low, family background of students who are less directing their children to always be orderly in life. As stated by Hibana, Kuntoro, and Sutrisno (2015) that this developing religious humanistic cultural in Islamic Schools is done by Islamic schools by stabilizing vision, building core team, building core class, and creating feedback classroom.

The challenges faced in the management of the cultural and environmental fields of the madrasah in the Madrasah Ibtidaiyah Muhammadiyah Unggulan Gorontalo, namely order and discipline are not yet optimal, because there are sometimes the presence of some picket teachers who sometimes attend between 07.15 to 07.30 , even though the picket teachers should be present at 07.00 according to the commitment which has been agreed by madrasah so that its contribution to order and discipline as well as service to madrasah in the initial activities before learning in the first hour becomes less optimal. Another challenge is that almost every day there are still some students who are late due to quite diverse reasons for example due to getting up late, the distance of the house is too far from the school and so forth which realistically the reasons submitted are still acceptable.

The author finds that the challenges faced in the management of the culture and environment of the madrasah are: (1) the lack of awareness of the madrasah civilizing civilization and maintaining existing facilities and infrastructure, (2) order enforcement and discipline that are not yet optimal sometimes there are teachers or staff who are not disciplined, resulting in a non-smooth learning process and an unfavorable example in front of students, (3) the family background of students who are less directing their children to always be orderly in life. Therefore, efforts are needed to overcome the various challenges that exist, one of which is to develop a culture of participation. As stated by Kholis, Zamrori and Sumarno (2015) that this culture is no less important to always be encouraged in an effort to accelerate the goals of the madrasah. The assumption is that the higher the level of participation the higher the quality of the institution. In fact, quality requires cooperation from various parties, including participation in madrasah programs and activities, both routine and incidental in nature that supports the achievement of academic quality and non-academic quality. As stated by Prayogo and Widodo (2019) the quality culture is a strategi to improve upon the institution towards the needs of society and become a long term goal of Indonesian education. As an educational institution characterized by Islam, madrasah must be able to fulfill the community needs on education of their children in order to avoid the negative effects of technological developments (Mulyadi, 2018). As stated by Sumarto (2019) are the success of benchmarking madrasas in realizing the quality structure and culture can be seen from an active commitment, a clear understanding of best industry practices, a desire must be based on benchmarking findings, a competency is always changing, a desire to share information with benchmarking partners.

\section{Conclusion}

The implementation of management in the field of culture and environment of madrasah in Madrasah Ibtidaiyah Private City of Gorontalo shows that the five Madrasah Ibtidaiyah focus on developing physical culture and behavioral culture. Physical culture can be seen from the facilities and infrastructure, school buildings that are equipped with fences, slogans, or writings on display in strategic places. Religious culture can be seen from a variety of religious activities held in each madrasah. Madrasah organizes activities that can support the creation of a religious atmosphere in the madrasah. Every morning before the lesson begins, it starts with the schedule along with the schedule attached to each class, memorizing short letters, prayers and reading prayers and reading the Qur'an. There are also extracurricular activities of reading and writing al-Qur'an, prayer duha, dzuhur, ashar, and friday prayer, recitation, and PHBI (the big Islamic ceremony days). In addition, Islamic writings and encouragement were also displayed which also contributed to the religious atmosphere in the madrasah. The five private Ibtidaiyah Madrasah in Gorontalo also developed a culture of achievement and competition and a culture of fond of reading. The culture of achievement and competition in these five madrasah is shown by the existence of events or events for achievement and competition. In addition, each madrasah also often 
sends students to participate in various competitions outside of school. This is intended so that students are motivated to be able to excel and compete with students from other schools so that they become champions and make the school proud. Madrasah also give awards to outstanding students and students who are active in the organization. The management of the cultural and environmental fields of Private Madrasah Ibtidaiyah continues to be done by always trying to increase the participation of all madrasah residents to optimize the facilities already owned both from learning tools and infrastructure facilities to support the culture that exists in the madrasah.

The challenges faced in implementing school culture in the Private Madrasah Ibtidaiyah in Gorontalo based on the findings show that teachers have not been able to fill their free time by reading but only sit chatting with other teachers and some even go home if there are no more teaching hours. In relation to that, the reconstruction of development that needs to be done by madrasah must make changes by familiarizing reading culture. The second challenge is the habit in terms of maintenance management, the habit of always caring for the goods owned must still be considered given the facilities, facilities and infrastructure of madrasah that are quite complete and adequate if not regulated in maintenance management this will certainly suck up the madrasah budget for procurement of goods returned. In this connection, the reconstruction of development that needs to be done by the madrasah to maximize the management of the madrasah culture and environment in Private Madrasah Ibtidaiyah in Gorontalo, namely: (1) must make changes by accustoming the culture of reading and care management to the sustainability of all activities in the madrasah; (2) every madrasah should increase the role of all madrasah residents by urging all madrasah residents to optimize the facilities that are already available both from learning tools and infrastructure facilities to support the culture that exists in the madrasah.

\section{References}

Abrori, M. S., \& Hadi, M. S. (2020). Integral values in madrasah: to foster community trust in education. Istawa: Jurnal Pendidikan Islam, 5(2), 160-178.

Anwar, H. (2017). Pengelolaan pendidikan di madrasah. Cirebon: Eduvision Press.

Anwar, S. (2014). Pengembangan budaya mutu dalam meningkatkan kualitas madrasah di Madrasah Ibtidaiyyah Negeri Kota Bandar Lampung. Analisis: Jurnal Studi Keislaman, 14(2), 455-489.

Asadullah, M. N., Amin, S., \& Chaudhury, N. (2019). Support for gender stereotypes: Does madrasah education matter? The Journal of Development Studies, 55(1), 39-56. doi: 10.1080/00220388.2017.1414190

Barnawi, B. (2013). Membangun budaya madrasah. INSANIA: Jurnal Pemikiran Alternatif Kependidikan, 18(3), 355-363.

Chaer, M. T. (2016). Peran madrasah dalam menghadapi era globalisasi dan budaya. Muaddib: Studi Kependidikan dan Keislaman, 6(2), 182-201.

Denzin, N. K., \& Lincoln, Y. S. (2005). Handbook of qualitative research. Thousand Oaks, California: Sage Publications.

Evans, A. (2008). Madrasah education: Necessity or rational choice? Harvard international review, 30(3), 58-61.

Hibana, H., Kuntoro, S. A., \& Sutrisno, S. (2015). Pengembangan pendidikan humanis religius di madrasah. Jurnal Pembangunan Pendidikan: Fondasi dan Aplikasi, 3(1), 19-30.

Hoel, N. (2016). Exploring women's madrasahs in South Africa: Implications for the construction of Muslim personhood and religious literacy. Religious Education, 111(1), 30-48. doi: 10.1080/00344087.2016.1124011.

Kalebbi, A. K. (2014). Building the culture of quality in Madrasah. Khazanah, 7(2), 58-65.

Kholis, N., Zamroni, Z., \& Sumarno, S. (2015). Mutu sekolah dan budaya partisipasi stakeholders. Jurnal Pembangunan Pendidikan: Fondasi dan Aplikasi, 2(2), 130-142.

Lathifah, A. F. U., \& Rustono, A. (2015). Pengaruh budaya organisasi terhadap kinerja karyawan madrasah ibtidaiyah negeri (MAN) Cimahi. eProceedings of Management, 2(2), 1164-1171. 
Muhaimin., Sutiah., \& Prabowo, S.L. (2015). Manajemen pendidikan (aplikasinya dalam penyusunan rencana pengembangan sekolah/madrasah). Jakarta: Prenada Media.

Mulyadi, E. (2018). Strategi pengembangan budaya religius di Madrasah. Jurnal Kependidikan, 6(1), 114. doi: 10.24090/jk.v6i1.1688.

Mutohar, P. M. (2016). Pengembangan budaya religius (religious culture) di madrasah: Strategi membentuk karakter bangsa peserta didik. Didaktika Religia, 1(1).

Nugraha, M. S., Maskar, D. K., \& Rohayani, A. (2016). Penguatan peran sekolah dalam pembiasaan akhlak mulia bagi siswa di era disrupsi. PROSIDING, 39.

Prayogo, S. A., \& Widodo, A. (2019). Membangun budaya mutu di madrasah unggul (Studi Kasus di MAN 1 Jember dan MA Unggulan Nurul Islam Jember). Journal EVALUASI, 3(1), 1-29.

Priatmoko, S. (2018). Memperkuat eksistensi pendidikan Islam di era 4.0. TA'LIM: Jurnal Studi Pendidikan Islam, 1(2), 1-19.

Sabki, A. i. A., \& Hardaker, G. (2013). The madrasah concept of Islamic pedagogy. Educational Review, 65(3), 342-356. doi: 10.1080/00131911.2012.668873

Sali, A. H. A., \& Marasigan, A. C. (2020). Madrasah education program implementation in the Philippines: an exploratory case study. International Journal of Comparative Education and Development, 22(3), 201-217. doi: 10.1108/IJCED-06-2019-0034.

Saminan, S. (2015). Internalisasi budaya sekolah Islami di Aceh. Jurnal Ilmiah Peuradeun, 3(1), 147164.

Sumarto, S. (2019). Benchmarketing madrasah membangun tatanan dan budaya mutu. Studi Multidisipliner: Jurnal Kajian Keislaman, 6(1), 125-145.

Supriyanto, D. (2015). Madrasah bermutu berbasis manajemen mutu terpadu (MMT). MODELING: Jurnal Program Studi PGMI, 2(1), 70-84.

Tan, C. (2009). The reform agenda for madrasah education in Singapore. Diaspora, Indigenous, and Minority Education, 3(2), 67-80. doi: 10.1080/15595690902762068

Tan, C. (2010). Contesting reform: Bernstein's pedagogic device and madrasah education in Singapore. Journal of Curriculum Studies, 42(2), 165-182. doi: 10.1080/00220270903494311

Yulianto, R. (2020). Implementasi budaya madrasah dalam membangun sikap moderasi beragama. EDUKASIA: Jurnal Pendidikan dan Pembelajaran, 1(1), 111-123.

Zuhriy, M. S. (2011). Budaya pesantren dan pendidikan karakter pada pondok pesantren salaf. Walisongo: Jurnal Penelitian Sosial Keagamaan, 19(2), 287-310. 